\title{
Research on the Strategy of Tianjin Port Container Sea-Rail Combined Transport
}

\author{
Tiantian Song ${ }^{1 *}$ \\ ${ }^{1}$ Transportation, Shanghai Maritime University, Shanghai, 201306, China.
}

\begin{abstract}
Tianjin Port has 3 container sea-rail combined transport channels leading to inland ports, and it is one of the intermodal transportation nodes of my country's "One Belt One Road" key construction. This paper introduces the development status of Tianjin Port's container sea-rail combined transport, uses SWOT to analyze the strengths, weaknesses, opportunities, and threats of the development of Tianjin Port's sea-rail combined transport, and proposes optimization strategies on this basis.
\end{abstract}

\section{Analysis on the Status Quo of Tianjin Port's Container Sea-Rail Combined Transport}

Tianjin port is located at the western end of Bohai Bay, relying on the newly established xiong'an new area. It connects Northeast Asia and Central and West Asia with Northeast, North China, and Northwest China. It is not only the maritime gateway of the Beijing-Tianjin-Hebei region, but also China, Mongolia, and Russia. The eastern starting point of the Three-Country Economic Corridor, an important node of the new Eurasian Continental Bridge and the strategic fulcrum of the 21st Century Maritime Silk Road. Statistics from Tianjin Port show that in 2019(As shown in Fig.1), Tianjin Port completed a cargo throughput of 492 million tons, a year-on-year increase of $4.1 \%$; the container throughput of 17,300,700 TEUs, an increase of $8.1 \%$. The steady growth of Tianjin Port's container traffic has brought huge opportunities for Tianjin Port's sea-rail combined transport.

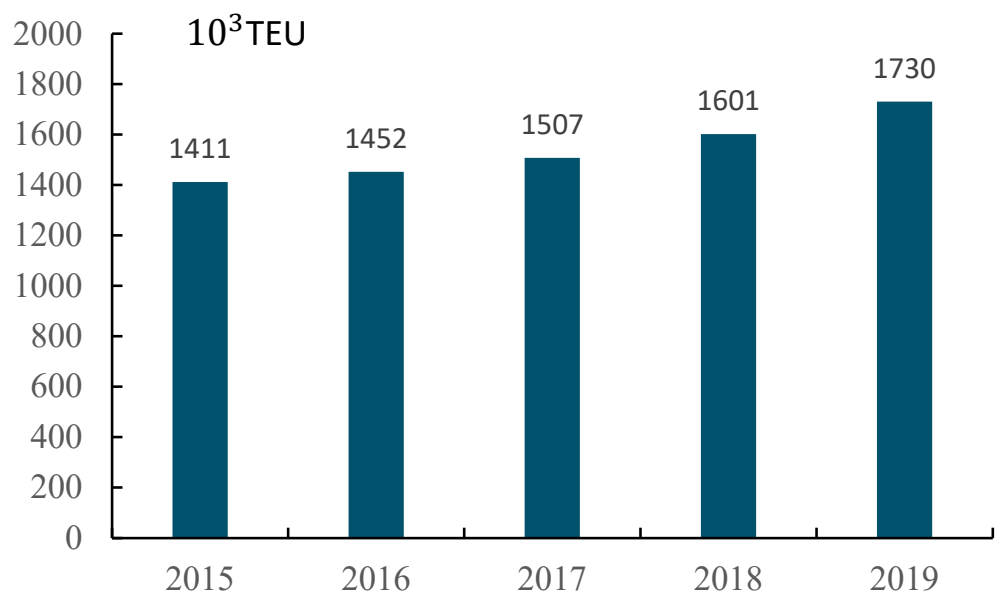

Fig. 1. Container throughput of Tianjin port in 2015-2019

Tianjin Port has vast land, water area and rich coastline resources, which is mainly composed of eight regions, namely northern, southern, Eastern, gaoshaling, Dagukou, Dagang, Beitang and Haihe port area. Dongjiang port area is an important part of China's free trade zone, which plays a carrier role as the core functional area of the north international shipping center. Because of the advantages of traditional infrastructure, coastline and bulk shipping, Beijiang port and Nanjiang port are conducive to focus on the construction of port public infrastructure, and focus on modern logistics, maritime trade, bulk product trading, port agent, fuel supply, industrial distribution, ship services and other projects, which is conducive to build a demonstration area for port transformation and upgrading. The southern port economic zone can gradually undertake the eastern and Northern Xinjiang port areas, transfer Ro / Ro vehicles, domestic trade containers and general cargo terminals, focus on terminal handling and high-end equipment manufacturing industry, comprehensive logistics industry, new health and new

\footnotetext{
*Corresponding author: 756332726@qq.com
} 
energy materials industry, and undertake the non capital functional industries of Beijing, aiming to create a port industrial cluster integrating "port production" Concentration area.The eastern area of Dagang Port area is a new space carrier to implement "Beiji Nansan"of Tianjin port, focusing on the construction of safe and green upgraded bulk logistics.

\section{SWOT analysis on the Development of Tianjin Port's Container Sea-Rail Combined Transport}

The strengths, weaknesses, opportunities, and threats of container sea rail intermodal transport in Tianjin port are shown in Table 1.

Table 1. Tianjin Port Container Sea-Rail Combined Transport SWOT Analysis Table

\begin{tabular}{|c|c|}
\hline Strengths & Weaknesses \\
\hline $\begin{array}{l}1 \text { Wide radiation range: Tianjin Port faces Japan, South } \\
\text { Korea, North Korea and other countries in Northeast Asia, } \\
\text { and is backed by my country's inland areas such as North } \\
\text { China and Northwest China. } \\
2 \text { The port is fully functional: Tianjin Port is the largest } \\
\text { comprehensive port in the north of the country. It has built } \\
\text { specialized berths for containers, coal, metal ore, } \\
\text { petroleum, steel and other goods. } \\
3 \text { Good port environment:Tianjin Port is one of the } \\
\text { largest comprehensive ports in my country, with an open } \\
\text { water area of nearly } 1,600 \mathrm{~km}^{2} \text {. }\end{array}$ & $\begin{array}{l}1 \text { Unbalanced freight volume: More than } 80 \% \text { of the } \\
\text { container throughput of Tianjin Port comes from Beijing, } \\
\text { Hebei, Shanxi and Inner Mongolia, and other regions } \\
\text { account for a relatively small amount of freight. } \\
2 \text { Natural conditions: There is a gap between the depth } \\
\text { and width of the port channel and the natural deep-water } \\
\text { port channel; Tianjin Port is located at the estuary of the } \\
\text { Haihe River, with a lot of sediment. } \\
3 \text { Low production efficiency of port collection and } \\
\text { distribution: The seamless connection between railway } \\
\text { and sea container transport stations is eliminated. }\end{array}$ \\
\hline Opportunities & Threats \\
\hline $\begin{array}{l}1 \text { National "One Belt One Road" Initiative: Tianjin Port } \\
\text { is one of the important strategic fulcrums for the } \\
\text { development and construction of the "Belt and Road" } \\
\text { initiative. } \\
2 \text { Implement the government's policy of "Transfer to } \\
\text { Railway": Since the national "Railway Transfer" policy } \\
\text { was promulgated, the Tianjin Municipal Government's } \\
\text { policy has been unprecedented, and the effect of railway } \\
\text { growth has been obvious. } \\
3 \text { Promotional role of Tianjin Pilot Free Trade Zone. }\end{array}$ & $\begin{array}{l}1 \text { Port competition to Tianjin Port's supply of goods: } \\
\text { The main domestic ports that compete with Tianjin Port } \\
\text { for supply are Yingkou Port, Lianyungang Port and Dalian } \\
\text { Port, and foreign ports include Japan's Kobe Port. } \\
2 \text { The needs of container sea-rail combined transport } \\
\text { customers tend to be individualized. } \\
3 \text { The sea-rail intermodal connection information is not } \\
\text { smooth enough: Have not yet established a unified } \\
\text { information exchange platform. }\end{array}$ \\
\hline
\end{tabular}

Through the analysis of the strengths, weaknesses, opportunities and threats of Tianjin Port, it can be concluded that the strengths of Tianjin Port's container sea-rail combined transport outweigh the weaknesses, and the opportunities outweigh the threats. Therefore, a growth-oriented SO strategy should be adopted, that is, Tianjin Port should make full use of its unique nature. Under advantageous conditions, it actively responded to the "One Belt, One Road" initiative and expanded the radiation scope of container sea-rail combined transport to Europe, North Asia, the Middle East and other regions.

\section{Optimization Strategy of Tianjin Port Container Sea-Rail Combined Transport}

\subsection{Increase the investment in the construction of railway collection and distribution}

It is an important measure to improve container sea-rail combined transport that the port and railway station are connected seamlessly to minimize the number of container loading and unloading. At present, the railway special lines have not all penetrated into the port area, and vehicles are still used for secondary loading and unloading, which not only affects the efficiency of container collection and distribution, but also increases the transportation costs of cargo owners. Therefore, Tianjin port should actively cooperate with Beijing port administration to reach an agreement on increasing investment in the construction of special railway line for port entry. It should also make great efforts to invest in the construction of container rail sea intermodal transport hub, improve the connection between the inverted loading line of storage yard and the hinterland railway network, effectively improve the transportation capacity of the line, ensure the smooth collection and distribution channel of container railway, and attract more container goods Source.

\subsection{Formulate a more reasonable container sea- rail combined transport freight rate}

The development potential of container sea-rail combined transport in Tianjin port is huge. As Dalian port, Yingkou port and other northern ports continue to expand the scope of container sea-rail combined transport business, Tianjin port should adjust the freight rate reasonably according to the change of market demand in low and peak seasons. In 
addition, Tianjin port should actively contact the freight center and make use of the price policy of China National Railway Group Co., Ltd. to give full play to the advantages of container sea rail combined transport. For the transportation demand of some mainland enterprises with large volume, we should take the initiative to implement the whole process logistics service, that is, we should not simply provide a single transportation service, but provide "door-to-door" whole process cargo transportation service.

\subsection{Build Tianjin Port Sea-Rail Combined Transport Information Platform Construction}

Container sea-rail combined transport can reduce transportation cost, shorten transportation time and improve service level, all of which depend on the rapidity and sharing of information exchange among relevant transportation departments.Most of the railway transportation enterprises related to sea-rail combined transport have established transportation production management system to realize the internal sharing of transportation information. At present, Tianjin Port has built an internal container sea-rail combined transport information management system, which is still in the perfect stage, and the data sharing between railway enterprises and ports has not yet been realized. Tianjin port should continuously invest capital and manpower to improve the system on the basis of the existing container sea rail intermodal transport information management system, and fully realize the data exchange and information sharing between enterprises and railway departments.

\subsection{Optimizing the train transportation organization of container Sea-Rail Combined Transport}

In order to establish a relatively complete, efficient, fast and safe container sea-rail combined transport system, Tianjin port should closely carry out business activities around railway container trains, cooperate with shippers, shipping companies and other customers, reduce intermediate links and realize common development. Therefore, the basis for developing container business of sea-rail combined transport is to operate railway container trains, take the trains as the means of transport, continuously improve the service level of sea-rail combined transport containers, ensure the stable operation of direct through, re-entry and fixed-time container trains between the port and inland container handling stations, reduce the vacancy rate of return journey, and improve the utilization efficiency of trains and containers.

\subsection{Strengthen the management of railway containers}

At present, Tianjin Port has not yet provided shipping companies with container storage space for leasing, nor has it opened container transportation business for shipping companies to solicit sources of goods. Therefore, in addition to the existing railway container storage, loading and unloading, disassembly and assembly, cleaning and container consignment business of Tianjin port railway container handling station, Tianjin port should seize the blank of railway container handling station, set up ship container return points in the yard of railway arrival line, and actively expand relevant supporting business. For imported container goods, it is not necessary to unpack at the port. When the goods are transported to the destination in the mainland and the operation is completed, the cargo owner can return the empty containers of the shipping company to the container yard of the company. For export container goods, Tianjin port can sign a container escrow agreement with the shipping company with the help of the container yard, that is, temporarily guarantee the empty containers of the shipping company Manage and charge a certain management fee. In this way, when the cargo owner needs to export goods, he can directly pick up the empty containers of the shipping company in the yard and load the goods.

\subsection{Improve the equipment level of Sea-Rail Combined Transport}

Purchase and use special flat cars for sea-rail combined transport scientifically and reasonably. Railway transport containers usually use dual-purpose flat cars and special flat cars to load and transport containers. However, dualpurpose flat cars of railway are no longer suitable under the trend of container specialization. Tianjin port should invest in the purchase of container special flat cars, increase the number of special flat cars, and promote the development of container sea-rail combined transport in Tianjin port.

We should actively operate double deck container trains and reasonably purchase different types of railway containers. The type of railway container has an important influence on the handling efficiency of sea-rail combined transport. The trend of international container sea rail combined transport is to operate double deck container trains. The reason is that under the condition of tight transport capacity in the same railway section, the volume of double deck container trains can be doubled. Therefore, Tianjin port should actively explore the operation of double deck container train to solve the problem of insufficient capacity in some railway transportation sections. In addition, Tianjin port should cooperate closely with Beijing Bureau Group Company on the basis of investment and purchase of different types of containers to achieve a win-win situation.

\subsection{Promote the development of human resources and the training of talents}

Build a comprehensive personnel training and selection mechanism to reserve sufficient human resources for Chinese enterprises in international competition. First of all, we should select the compound international logistics business talents jointly cultivated by the top universities in the professional field at home and abroad to form a 
professional talent training system; second, we should establish a multinational professional talent training base, combine theory with practice, select outstanding young employees of enterprises for training, and improve the quality of talents; third, we should set up an expert forum to disseminate excellent experience; fourth, we should build a talent training base Establish a fair, just and open talent selection mechanism, so that everyone can play their skills in the post.

\section{Conclusion}

To sum up, the development of sea-rail intermodal transport plays an important role in further optimizing the logistics environment, reducing logistics costs and promoting the development of logistics industry.It has an important practical significance to enhance the import and export trade volume of Tianjin and related inland areas, and promote the coordinated development of Beijing Tianjin Hebei region. For Tianjin and its surrounding areas, the development of container sea-rail combined transport is conducive to the development of regional economy, the adjustment and upgrading of industrial structure, so as to promote the coordinated development of Beijing Tianjin Hebei region, and promote the economic hinterland of North China, northeast and northwest to enhance the overall strength of regional economic and social development. For Tianjin port, one belt, one road, is to develop the container sea-rail combined transport, which will give full play to Tianjin's own advantages and further promote the transformation and upgrading of port business, so as to achieve the goal of building a world-class port and further deepen the "one belt and one road" initiative so as to truly realize the interconnection between China and the countries along the border, and constantly form a new pattern of opening to the world.

\section{Reference}

1. Linying Zhang.The trade pattern and economic contribution between China and the countries along the "Belt and Road"[J].Market Modernization, 2017(06): 17 .

2. Xinlong Hu.Research on Container Multimodal Transport Information System[J]. navigation, 2018(05):68.

3. BRIDGES S. Real-time Control of Freight Forwarder Transportation Networks by Integrating Multimodal Transport Chains[J]. Transport Policy, 2004,11(3): 266-275.

4. Button K J.Transport Economics[J]. Books, 2015(3): 42 . 